\title{
Correction to: Eculizumab: A Review in Generalized Myasthenia Gravis
}

\author{
Sohita Dhillon ${ }^{1}$
}

Published online: 9 March 2018

(C) The Author(s) 2018. This article is an open access publication

Correction to: Drugs 78(3):367-376 (2018)

https://doi.org/10.1007/s40265-018-0875-9

The article Eculizumab: A Review in Generalized Myasthenia Gravis, written by Sohita Dhillon, was originally published Online First without open access. After publication in volume 78 , issue 3, pages 367-376 Alexion Pharmaceuticals Inc. requested that the article be Open Choice to make the article an open access publication. Post-publication open access was funded by Alexion Pharmaceuticals Inc. Further details may be found at http:// www.medengine.com/Redeem/39FCF0602D6721C2. The article is forthwith distributed under the terms of the Creative Commons Attribution-NonCommercial 4.0 International License (http://creativecommons.org/licenses/bync/4.0/), which permits any noncommercial use, duplication, adaptation, distribution and reproduction in any medium or format, as long as you give appropriate credit to the original author(s) and the source, provide a link to the Creative Commons license and indicate if changes were made.

Open Access This article is distributed under the terms of the Creative Commons Attribution 4.0 International License (http://creativecommons.org/licenses/by/4.0/), which permits unrestricted use, distribution, and reproduction in any medium, provided you give appropriate credit to the original author(s) and the source, provide a link to the Creative Commons license, and indicate if changes were made.
The original article can be found online at https://doi.org/10.1007/ s40265-018-0875-9.

\section{Sohita Dhillon}

demail@springer.com

1 Springer, Private Bag 65901, Mairangi Bay, Auckland 0754, New Zealand 